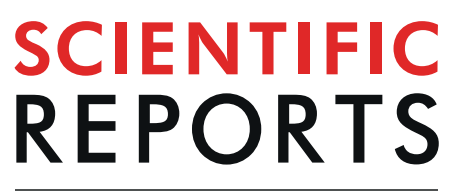

natureresearch

Check for updates

\title{
OPEN
}

Published online: 09 June 2020

\section{Author Correction: Structural and dynamic studies reveal that the Ala-rich region of ataxin-7 initiates $\alpha$-helix formation of the polyo tract but suppresses its aggregation}

Jun-Ye Hong, Wei Xue, Hong-WeiYue, HuiYang, Lei-Lei Jiang, Hong-Yu Hu, Dong-Dong Wang \& Wen-Ning Wang

Correction to: Scientific Reports https://doi.org/10.1038/s41598-019-43926-9, published online 16 May 2019

The original version of this Article omitted an affiliation for Jun-Ye Hong, Wei Xue and Hong-Wei Yue.

The correct affiliations for Jun-Ye Hong, Wei Xue and Hong-Wei Yue are listed below:

State Key Laboratory of Molecular Biology, Shanghai Institute of Biochemistry and Cell Biology, Center for Excellence in Molecular Cell Science, Chinese Academy of Sciences, Shanghai 200031, P. R. China

University of Chinese Academy of Sciences, Beijing 100049, P. R. China

This has now been corrected in the HTML and PDF versions of this Article

(c) (i) Open Access This article is licensed under a Creative Commons Attribution 4.0 International (c) License, which permits use, sharing, adaptation, distribution and reproduction in any medium or format, as long as you give appropriate credit to the original author(s) and the source, provide a link to the Creative Commons license, and indicate if changes were made. The images or other third party material in this article are included in the article's Creative Commons license, unless indicated otherwise in a credit line to the material. If material is not included in the article's Creative Commons license and your intended use is not permitted by statutory regulation or exceeds the permitted use, you will need to obtain permission directly from the copyright holder. To view a copy of this license, visit http://creativecommons.org/licenses/by/4.0/.

(C) The Author(s) 2020 